\title{
THE TOURISM DEVELOPMENT THROUGH CBT IN PONGGOK VILLAGE
}

\author{
Ade Pugara1a, Brian Pradana $2^{\text {b }}$ \\ aPSDKU Universitas Diponegoro; Semarang, Indonesia; ade.pugara@live.undip.ac.id \\ Info Artikel: \\ bPSDKU Universitas Diponegoro; Semarang, Indonesia; brian.pradana@live.undip.ac.id \\ - Artikel Masuk: 01/03/21 \\ - Artikel diterima: 20/03/21 \\ - Tersedia Online: 30/03/21

\begin{abstract}
ABSTRAK
Community-based tourism (CBT) merupakan salah satu pendekatan yang populer dalam pengembangan pariwisata. Prinsip utama CBT adalah memberikan akses kepada masyarakat dalam pengelolaan dan pengembangan pariwisata secara merata. Selanjutnya tujuan utama CBT adalah mewujudkan pemberdayaan masyarakat di bidang pariwisata. Oleh karena itu, komunitas memiliki keunggulan kompetitif untuk meningkatkan kualitas pariwisata dan mempertahankannya (Hausler dan Strasdas, 2003).

Pada tahun 2015 Ponggok menerima Dana Desa dari pemerintah pusat. Melalui anggaran tersebut, pemerintah daerah membentuk Badan Usaha Milik Desa (BUMDes) yang fokus pada pengembangan pariwisata. Dalam pengembangan pariwisata, Ponggok memanfaatkan mata air Pongok sebagai daya tarik utama.. Berdasarkan fakta tersebut, maka penelitian ini ingin mengkaji "apakah keberhasilan pengembangan pariwisata di Desa Ponbgok termasuk dalam Community Based Tourism (CBT)" ?. Penelitian ini menggunakan metode deduktif - kualitatif - rasionalistik. Teknik analisis penelitian ini adalah deskriptif kualitatif, komparatif dan kontras.

Pengembangan pariwisata Ponggok sesuai dengan prinsip, karakteristik dan dimensi pembangunan yang berbasis masyarakat. Hal tersebut memungkinkan masyarakat setempat untuk mengontrol dan terlibat dalam pengelolaan pariwisata. Selain itu, menarik pemberdayaan masyarakat dan berbagi manfaat pengembangan pariwisata kepada pelaku langsung dan tidak langsung. Dalam situasi saat ini, semua orang memiliki pekerjaan, dan angka kemiskinan dapat dikurangi secara signifikan.
\end{abstract}

Kata Kunci : Pariwisata; Pembangunan; Masyarakat

\begin{abstract}
Community-based tourism (CBT) is the most popular approaches in tourism development. The main principle of CBT is giving access to the community in tourism management and development equally. Furthermore, the main goal of CBT is creating community empowerment in tourism. Therefore, the community has competitive advantages to enhance tourism quality and keep it sustain (Hausler and Strasdas, 2003).

.In 2015 Ponggok received the village Annual Budget (Dana Desa) from the central government. Through that budget, the local government establish the Village Company (BUMDes), which is focusing on tourism development. In the tourism development, Ponggok attempt to use Pongok water springs as the main tourist attraction.. Based on these facts, this research wants to examine "is the successes of tourism development in Ponbgok Village belongs to Community-based tourism (CBT)"? This research uses the deductive - qualitative - rationalistic method. The analytical techniques of this research are descriptive qualitative, comparative and contrast.

The tourism development of Ponggok appropriate to the principle, characteristic and dimension of community-based development. It allows the local community to control and involved in tourism management. Moreover, it attracts community empowerment and shares the benefit of tourism development to direct and indirect actors. In the current situation, all people have a job, and the number of poverty can be decreased significantly.
\end{abstract}

Keyword: Tourism; Development; Community

\section{INTRODUCTION}

Rural in Indonesia is recognized as left behind the area with a high poverty level as a mental issue. This condition commonly results in the unavailability of the local government to optimize the rural resource and conduct the development properly. Furthermore, the lack of human resources makes the rural area still in the worst situation. The younger generation of the rural area prefers moves to the town to work in their homeland. In their paradigm, they become industrial labour better than any other occupation in the rural area. Depend on this rural problem, the central government considering the policy to improve the development through Village Annual Budget Allocation or "Alokasi Dana Desa" (ADD). This program directly transfers the development budget to the local 
government. Thus, the local government can implement rural development planning effectively.

Ponggok village is one of the rural areas where receive the Village Annual Budget Allocation from the central government. By using the Village Annual Budget Allocation, the local government improve the village revenue, decrease unemployment dan increase the villager's income. The first step in change the rural condition in establishing the Village Corporation. The corporation role to manage all economic activity in The Ponnggik Village and to maximize the natural resources. Besides that, the local government (village government) stimulating the empowerment of the people by providing education and socialization regarding tourism management and the possibility of people participating in that program.

\section{DATA AND METHOD}

\subsection{Data}

Ponggok village has a five water springs as a natural potency, they are Ponggok, Sigedang, Kapilaler, Cokro and Besuki. Among them, the Ponnggok Water spring is the biggest one. It has $70 \mathrm{~m}$ in length, $40 \mathrm{~m}$ wide and 735 I/second water debit. The existence of the water spring in Ponggok Village is caused by geographical condition. Specifically, It locates in the valley between Merapi and Merbabu Mount. With that potency, the community use it to drive economic activity such as fishery and agriculture. Besides that, the water spring is also used by the local water company (PDAM) as raw water material. Thus, the water company pay some money to the local government (pemerintah desa) as compensate.

Unfortunately, that local economic activity does not effective to increase community welfare. It is indicated by the high unemployment number of the younger generation until many villagers in debt to the rentenir or small bank called "bank plecit". Those conditions make the community live in poverty with per capita income of only Rp. 300.000 - Rp 400.000 per month.

In 2009 the head of Ponggok Village, Junaedi Mulyono, tried to face the problem by establishing the village company called BUMDes Tirta Mandiri. This company attempt to manage fishery and farming activity. The role of the village company in fishery and agriculture consists of :

1. Provide the quality seeds of fish and paddy;

2. Advice the water usage of fishery and farming;

3. Promote the product to the market;

4. Promote the added value of fishery and agriculture products.

Trough BUMDes Tirta Mandiri the local economy can improve the community welfare and increase the village revenue in between 400 million rupiahs per years. However, the head of the village aims to get higher community quality live improvement. Thus, he promotes tourism trough water spring. This idea comes from the philosophy: the water is a source of life". The political will of the village government inherent with the central government in case of rural development trough Village Annual Budget Allocation.

In 2015 Ponggok Village received ADD budget from the central government of about 1 billion rupiahs. Through that budget, ponggok build water tourism based on the water springs, especially Ponggik Water Spring. Ponggok introduces many kinds of tourism attracting such as diving, snorkelling, water playground and fishing ground. Trough, the water tourism Ponggok, earns 600 million rupias per month or equal with 7,2 billion per mount. The revenue divided into four usages. $30 \%$ of them become a village government budget, $30 \%$ for operational, $30 \%$ form BUMDes Capital Saving and 10\% for corporate social responsibility. Nowadays, BUMDes Tirta Mandiri hires about 82 workers in the tourism sector. All $f$ them is the Ponggok Villagers. They earn a salary higher than the standard regional income of Klaten Regency per mount. Besides that, the existence of Umbul Ponggok creates many informal sectors in food vendor, homestay, transportation sectors and others. The multiplayer effect of water tourism in the Ponggok Village face unemployment and poverty problem. Recently all younger generations have an occupation both in the formal and informal sector). 


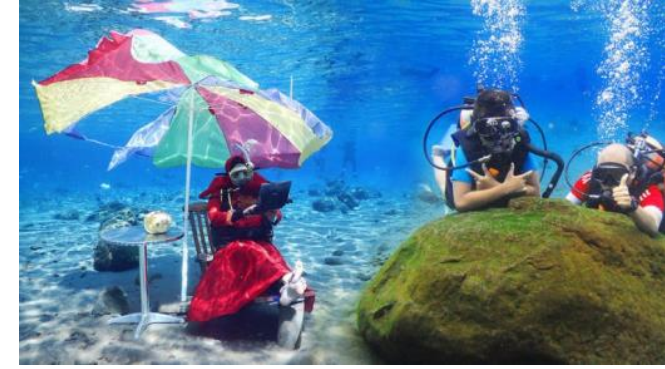

Figure. 1. Underwater Photography

(Observation, 2019)

The first attraction in Ponggok Village is underwater photography. This attraction diving activity mixed with photography in the water. In the water, the tourist can take a picture with several things which commonly find in daily life such as a motorcycle, bike and television. On the water, they can take action look like doing the daily activity and capture that moment. This attraction requires the diving ability for the tourist who wants to do it.

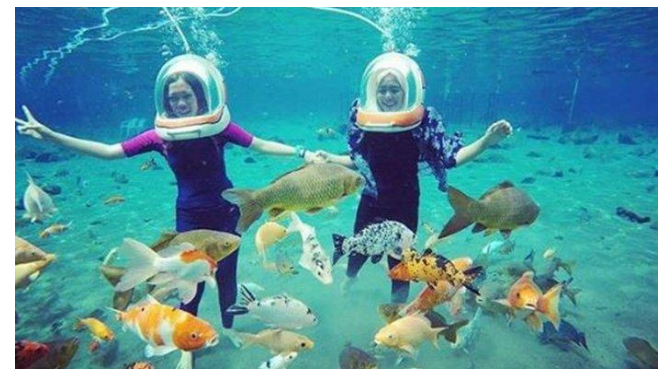

Figure. 2. Walker (Observation, 2019)

Walker is the tourist attraction which offers the experience in underwater without diving skill. The tourist should wear a transparent helmet that has a pipe to breathe. Trough this toll, they can interact with fish in the water and can walk around the water springs. The walker is usually used by the adult to enjoy the water springs.

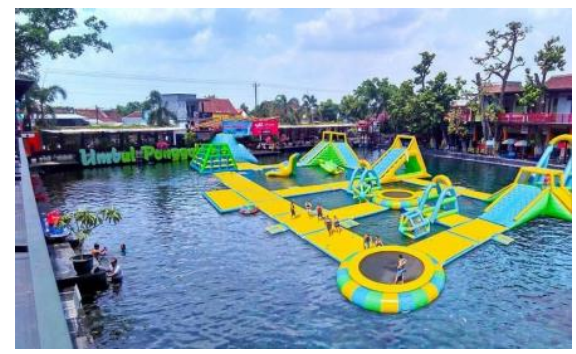

Figure 3. Ponggok Ninja Warior (Onsevation, 2019)
The Ponggok Ninja Warrior is like a water playground and adopts the Ninja Warrior television show concept. This playground consists of many games which have a different challenge. At this playground, the tourist can try their agility like jump, run and so on. The Ninja Warrior Playground located in the middle of the water spring. It is usually played by children to enjoy the water spring.

In term of tourism promotion, BUMDes Tirta Mandiri uses the internet to attract tourism coma to enjoy Ponggok Water Spring. They use many kinds of social media such as Facebook, Twitter, Instagram and vacation blog. Moreover, this destination became more popular because of many vlogs on youtube. The Instagram-able: image make Ponggok Water Springs popular with the younger generation. The promotion is conduct by the community and organized by BUMDes.

\subsection{Method}

The research regarding "The Tourism Development Towards CBT in Ponggok Village" use the deductive - qualitative - rationalistic approach. The deductive is conducted by search the theory regarding Community-Based Tourism. Secondly, decide the appropriate study area where CBT and tourism development are implemented. Thirdly collect the empirical fact and the data from the study area. The last is comparing the theory and empirical data.

The qualitative method is chosen because this research based on qualitative facts such as the role of community, an initiative of community and participation. The qualitative method involves the analysis tool of the study. Thus, it uses descriptive qualitative, comparative and qualitative normative as the analysis tools. The qualitative also make the data deeper to illustrate the condition because considering the intangible aspect of the community.

In the collecting data phase, this research uses the primary and secondary technique. The primary is conducted by interview and observation. The secondary is conducted by the literature study. In the interview, this research using purposive sampling. The respondent of the interview is the chief of the village, the manager of BUMDes and the people who involve in tourism development. The observation is 
conducted by direct observation and take a picture to collect the empirical data

\section{RESULT}

Ponggok water spring is a tourist destination that can be developed trough Village Annual Budget Allocation and community empowerment. Ponggok tourism development can be categorized as a success story of tourism development with a CBT approach. It fulfils the principle of CBT.

Table 1. CBT Principle Compare to

Ponggok Condition (Analysis, 2021)

\begin{tabular}{|c|c|c|}
\hline Num & $\begin{array}{c}\text { CBT } \\
\text { Principle }\end{array}$ & Ponggok Condition \\
\hline \multirow[t]{2}{*}{1} & $\begin{array}{l}\text { Allow the local } \\
\text { community to } \\
\text { control and } \\
\text { involved in } \\
\text { tourism } \\
\text { management. }\end{array}$ & $\begin{array}{l}\text { Ponggok water spring is } \\
\text { the natural potency located } \\
\text { in Ponggok Village. Thus, } \\
\text { everyone in Ponggok } \\
\text { Village has a responsibility } \\
\text { to conserve and rights to } \\
\text { use. }\end{array}$ \\
\hline & & $\begin{array}{l}\text { Trough BUMDes Tirta } \\
\text { Mandiri, the community, } \\
\text { can involve in the tourism } \\
\text { development and become } \\
\text { an actor to manage the } \\
\text { tourism in Ponggok }\end{array}$ \\
\hline 2 & $\begin{array}{l}\text { The } \\
\text { community } \\
\text { who has } \\
\text { undirect } \\
\text { involvement in } \\
\text { the tourism } \\
\text { development } \\
\text { still receive } \\
\text { the benefit } \\
\text { from the } \\
\text { tourism } \\
\text { development }\end{array}$ & $\begin{array}{l}\text { Ponggok Tourism is not } \\
\text { only giving a benefit to the } \\
\text { villagers who involve } \\
\text { directly in tourism } \\
\text { management but also } \\
\text { another person in that } \\
\text { surrounding area. The } \\
\text { multiplayer effect of tourism } \\
\text { creates several occupations } \\
\text { in the informal sector, such } \\
\text { as street food vendor, } \\
\text { homestay and } \\
\text { transportation sector. }\end{array}$ \\
\hline 3 & $\begin{array}{l}\text { Require } \\
\text { community } \\
\text { empowerment } \\
\text { and equally } \\
\text { benefit } \\
\text { distribution. }\end{array}$ & $\begin{array}{l}\text { The BUMDes open the } \\
\text { member of the community } \\
\text { to be a direct shareholder. It } \\
\text { means the benefit of } \\
\text { tourism distributes directly } \\
\text { to them. } \\
\text { The tourism destination } \\
\text { hires about } 82 \text { local workers } \\
\text { from this village. It is a kind } \\
\text { of benefit in term of creating } \\
\text { employment. }\end{array}$ \\
\hline
\end{tabular}

\begin{tabular}{|c|c|c|}
\hline Num & $\begin{array}{c}\text { CBT } \\
\text { Principle }\end{array}$ & Ponggok Condition \\
\hline & & $\begin{array}{l}\text { The multiplayer effect } \\
\text { creates the street food } \\
\text { vendor. The raw material of } \\
\text { street food comes from } \\
\text { fishery and farming activity } \\
\text { such as corn, Nila fish and } \\
\text { cassava. In this part, } \\
\text { tourism allows the fishery } \\
\text { and agriculture to support it. }\end{array}$ \\
\hline
\end{tabular}

Based on the table above, Umbul Ponggok suitable for the principle of CBT in term of tourism development. On the other hand, the comparison tool to examine the suitability of tourism development in Ponggok with CBT is continued through CBT characteristic. The comparison between CBT characteristic with the condition in Ponggok is in the table below.

Table 2. CBT Characteristic Compare to Ponggok Condition. Analysis, 2021)

\begin{tabular}{|c|c|c|}
\hline Num & $\begin{array}{c}\text { CBT } \\
\text { Characteristic }\end{array}$ & Ponggok Condition \\
\hline 1 & $\begin{array}{l}\text { Community } \\
\text { authorize, } \\
\text { support and } \\
\text { develop } \\
\text { tourism. }\end{array}$ & $\begin{array}{l}\text { Ponggok people } \\
\text { realize that the water } \\
\text { spring is God giving, } \\
\text { and they have to } \\
\text { conserve and use it } \\
\text { wisely. } \\
\text { Water is the basic } \\
\text { need to live. It can be } \\
\text { used in many kinds of } \\
\text { daily life. Based on this } \\
\text { philosophy, Ponggok } \\
\text { people create water } \\
\text { tourism. }\end{array}$ \\
\hline 2 & $\begin{array}{l}\text { Involving the } \\
\text { community in } \\
\text { member in } \\
\text { every step of } \\
\text { tourism } \\
\text { development }\end{array}$ & $\begin{array}{l}\text { BUMDes and tourism } \\
\text { development are } \\
\text { encouraged } \\
\text { Ponggok people. }\end{array}$ \\
\hline 3 & $\begin{array}{l}\text { Developing the } \\
\text { community } \\
\text { spirit and pride }\end{array}$ & $\begin{array}{l}\text { Water spring tourism } \\
\text { makes Ponggok } \\
\text { People pride and } \\
\text { thankful for the } \\
\text { existence of the water }\end{array}$ \\
\hline
\end{tabular}




\begin{tabular}{|c|c|c|}
\hline \multirow[t]{2}{*}{ Num } & \multirow{2}{*}{$\begin{array}{c}\text { CBT } \\
\text { Characteristic }\end{array}$} & Ponggok Condition \\
\hline & & $\begin{array}{l}\text { spring, which can } \\
\text { improve their quality of } \\
\text { life. }\end{array}$ \\
\hline 4 & $\begin{array}{l}\text { Improving } \\
\text { community life } \\
\text { quality }\end{array}$ & $\begin{array}{l}\text { Before tourism } \\
\text { development in } \\
\text { Ponggok, } \\
\text { unemployment and } \\
\text { poverty are commons } \\
\text { phenomena there. } \\
\text { After tourism } \\
\text { development, there is } \\
\text { no unemployment, and } \\
\text { the people welfare } \\
\text { improve significantly } \\
\text { trough direct or indirect } \\
\text { benefit. }\end{array}$ \\
\hline 5 & $\begin{array}{l}\text { Guaranteeing } \\
\text { environment } \\
\text { sustainability }\end{array}$ & $\begin{array}{l}\text { One of the best } \\
\text { strategies to conserve } \\
\text { the environment } \\
\text { makes it as collective } \\
\text { ownership. Toward it, } \\
\text { the community feel } \\
\text { they are also own the } \\
\text { water spring and have } \\
\text { a willingness to keep } \\
\text { the environment } \\
\text { sustain because they } \\
\text { realize that it can } \\
\text { improve their welfare. }\end{array}$ \\
\hline 6 & $\begin{array}{l}\text { Keeping the } \\
\text { local content } \\
\text { and culture }\end{array}$ & $\begin{array}{l}\text { Tourism development } \\
\text { does not leave the } \\
\text { other local economic } \\
\text { activity such as fishery } \\
\text { and agriculture, } \\
\text { because people can } \\
\text { sell the product in that } \\
\text { place. }\end{array}$ \\
\hline 7 & $\begin{array}{l}\text { Supporting the } \\
\text { tourism } \\
\text { knowledge } \\
\text { exchange }\end{array}$ & $\begin{array}{l}\text { The success story of } \\
\text { the tourism } \\
\text { development in } \\
\text { Ponggok makes many } \\
\text { other villages want to } \\
\text { learn from them. } \\
\text { Ponggok village is } \\
\text { open to study visit from } \\
\text { other villages in term of } \\
\text { ADD usage to develop } \\
\text { tourism. }\end{array}$ \\
\hline
\end{tabular}

\begin{tabular}{|c|l|l|} 
Num & \multicolumn{1}{c}{ CBT } & \multicolumn{1}{c}{ Ponggok Condition } \\
\hline 8 & $\begin{array}{l}\text { Respect in } \\
\text { cultural } \\
\text { diversity }\end{array}$ & $\begin{array}{l}\text { Ponggok village does } \\
\text { not differentiate the } \\
\text { visitor based on } \\
\text { anything Everyone } \\
\text { around the world can } \\
\text { visit and enjoy the } \\
\text { water spring. }\end{array}$ \\
\hline 9 & $\begin{array}{l}\text { Distribute the } \\
\text { benefit to the } \\
\text { member } \\
\text { equally }\end{array}$ & $\begin{array}{l}\text { Umbul } \\
\text { creates a direct and } \\
\text { indirect benefit in } \\
\text { social and economic. } \\
\text { The Ponggok people } \\
\text { who either have direct } \\
\text { or indirect involvement } \\
\text { receive that benefit. }\end{array}$ \\
\hline $\mathbf{1 0}$ & $\begin{array}{l}\text { Optimizing the } \\
\text { community } \\
\text { involvement } \\
\text { involved in tourism } \\
\text { development from the } \\
\text { idea up to tourism } \\
\text { management. }\end{array}$ \\
\hline
\end{tabular}

Based on the table above, Umbul Ponggok generally has the same characteristic as the CBT approach. The only one un full suitable with CBT characteristic is in the pluralism point. Because Umbul Ponggok does not create culture attraction. The last comparative tools are the CBT dimension. The comparison between the CBT dimension and the actual condition in Ponggok is in the table below.

Table 3. CBT Dimension Compare to Ponggok Condition Analysis, 2021)

\begin{tabular}{c|l|l|} 
Num & \multicolumn{1}{c}{$\begin{array}{c}\text { CBT } \\
\text { Dimension }\end{array}$} & \multicolumn{1}{c}{ Ponggok Condition } \\
\hline 1 & Economy & $\begin{array}{l}\text { Umbul Ponggok tourism } \\
\text { is developed trough } \\
\text { ADD, and it gives direct } \\
\text { and indirect economic } \\
\text { benefit such as income } \\
\text { for the village, income for } \\
\text { workers, multiplayer } \\
\text { effect, and creates } \\
\text { employment. } \\
\text { Umbul Ponggok can } \\
\text { work properly because of } \\
\text { the role and community }\end{array}$ \\
\hline 2 & Social &
\end{tabular}




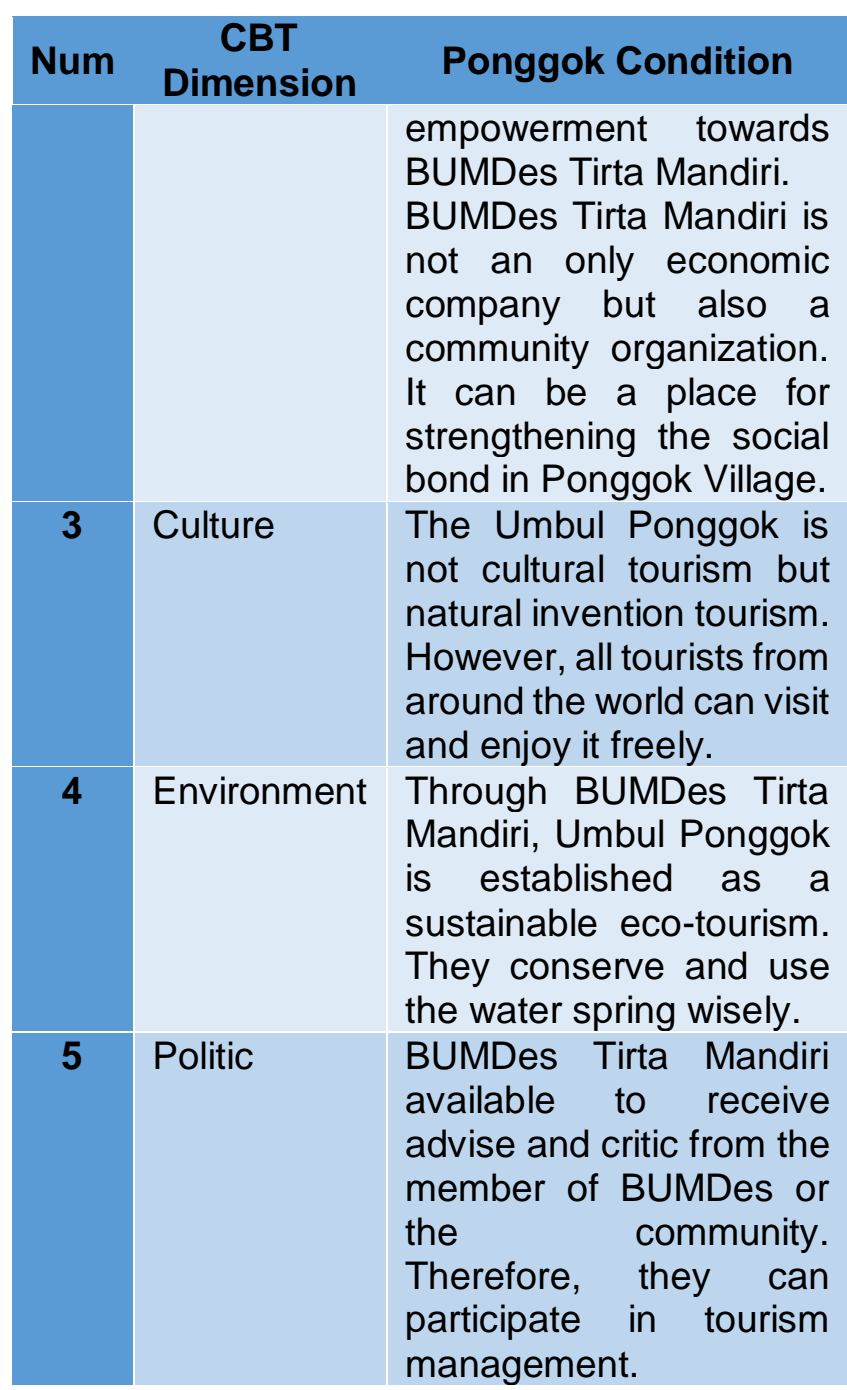

Based on the table above, 4 dimensions of the CBT are appropriate with the tourism development in Ponggok Village. However, the culture dimension does not match with Ponggok condition. Generally, the tourism development in Ponggok Village towards ADD is appropriate with CBT in principle, characteristic and dimension. In this case, the CBT approach is a success to create community empowerment and tourism in Ponggok Village

\section{COMCLUSSION}

Ponggok people realize that the water spring in their village is the natural potency to develop their economy and improve the quality of life. Therefore, Ponggok makes over the water spring become modern tourism which has underwater photography, walker and ninja warrior water playground as the attraction. The right strategy in choosing the attraction make Umbul Ponggok become popular. Moreover, the younger generation strongly related to social media such as Instagram and Twitter. So that they look for a good place the take a picture ad uploads it to their social media. One of the Instagram-able places for the younger generation is Umbul Ponggok.

Ponggok Village is one of success place to develops tourism towards ADD. In the process of tourism development, the local government attract and encourage community empowerment. Therefore, Ponggok promotes BUMDes Tirta Mandiri as the manager of tourism. BUMDes Tirta Mandiri is not only an economic company but also a social company. It attracts the participation of the community to give their idea, advice and critic for tourism sustainability. Moreover, BUMDes Tirta Mandiri can be a place to strengthening the social bond and modal social of Ponggok people.

Umbul Ponggok produces significant revenue for the village and community. From ticket, they earn 600 million per month or 7,2 billion per years. Besides that, the multiplayer effect of the Umbul Ponggok creates informal sector such as food street vendors, homestay and transportation sector. It means Ponngok Water springs give a benefit for direct and indirect involvement. That fact in Ponggok tourism development appropriate to communitybased tourism. Thus, it can be identified that the successes of Ponggok Tourism are because they use community-based tourism as the tourism development approach.

\section{REFERENSI}

Esterberg, K, G. (2002). Qualitative Methods In Social Research. New York: Mc Graw Hill. Garrod,Brian. (2001). Local Participation In The Planning And Management Of EcoTourism : A Revised Model Approach. Bristol : University Of The West England Press

Hausler, N and Strasdas, W. (2002). Training Manual for Community Based Tourism. Geemany : Inwent. 
Moleong, L. (2013). Metode Penelitian Kualitatif. Edisi Revisi. Bandung : PT. Remaja Rosdakarya.

Remaja Rosdakarya. Suansri, P, (2003). Community Based Tourism Handbook. Thailand : REST Project. 